
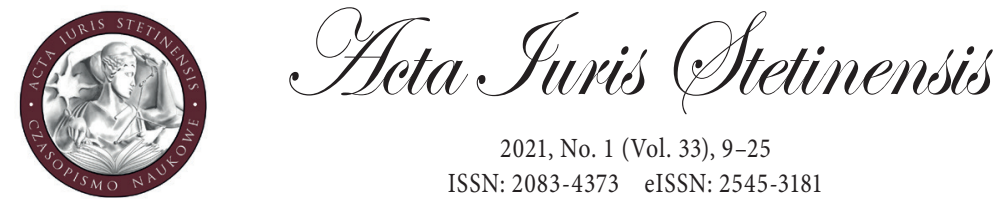

2021, No. 1 (Vol. 33), 9-25

ISSN: 2083-4373 eISSN: 2545-3181

DOI: $10.18276 /$ ais.2021.33-01

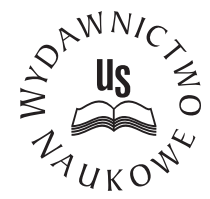

Aurelia Bajerska

MA

University of Szczecin, Poland

Faculty of Economics, Finance and Management

e-mail: aurelia.bajerska@phd.usz.edu.pl

ORCID ID: 0000-0002-8694-4154

\title{
Sources of tax law in the Polish legal system
}

\begin{abstract}
In the literature, the sources of law are considered to be "a formalised act of state authority containing legal provisions". In order to assess the nature of a designated act of state authority as a source of law, its form and the appropriate procedure are important. Therefore, the basic objective of the article is to demonstrate the sources of making tax law, with a particular emphasis on their classification in the tax law system. In fact, the position of particular types of sources of law in the system depends on three types of factors, such as: the position in the system of public authorities from which the source of law comes, its contents and the mode of its creation. Only a cumulative analysis of these three factors allows the prioritization of the legal acts constituting the sources of tax law. Despite notable achievements in the body of relevant literature, an attempt was made to re-analyse it in order to systematize the concepts and principles related to the subject matter in question. Furthermore, the jurisprudence was examined to emphasize that the sources of tax law also constitute a matter of argument in the judicature. Analysis of legal regulations in force and empirical methods were used as the basis for the study.
\end{abstract}

Keywords: tax law, hierarchization, sources of law

1 Encyklopedia zarzadzania, https://mfiles.pl/pl/index.php/\%C5\%B9r\%C3\%B3d\%C5\%82a_prawa (accessed 2.11.2020). 


\section{Introduction}

The concept of law sources is an accurate translation of the Latin phrase fons iuris. This term is polysemantic due to the fact that it can be interpreted from various points of view. Acts of legislative bodies issued within their competences and forms provided for by the law are considered to be the sources of law. In such a case the sources of law are interpreted in their formal meaning. However, in the substantive meaning, the sources of law are defined from the point of view of factors influencing the contents of a given legal norm. Therefore, these are phenomena that have both direct and indirect impact on the subject matter of binding law. The validation depiction of law sources can also be discussed where in the course of applying law - the normative basis, resolution of a given case is searched for. ${ }^{2}$ Legal scholars and commentators classify law sources into so-called sources of making law and sources of knowledge on the law, which de facto refer to the aforementioned division into law sources in substantive and formal meaning. Sources of knowledge on the law in the legal scholarship are commonly understood to be all types of documents and objects on the grounds of which contents of legal norms can be determined. ${ }^{3}$ They are understood to be the phenomena that have both direct and indirect impact on the subject matter of binding law. The indicated phenomena include social, economic, political and ideological factors. In turn, the sources of the knowledge on the law should be considered to be all premises regarding information on the law. ${ }^{4}$

There are many definitions of law sources in the literature. According to one of them, a source of law may be an entity who stipulates the law, i.e. an entity that makes or recognises legal norms. In the past, the so-called source of law referred to a monarch. Currently, in democratic states, the source of law should be understood as the general public - the nation. ${ }^{5}$ In order to assess the nature of a designated act of a state authority as a source of law, its form is important. "The law is, in fact, the will of the state that is demonstrated in the required form and relevant mode". ${ }^{6}$ Thus, not every decision of a state body is a source of law. Sources of law consist of, in fact, only those decisions of public authorities which result in creating new norms or recognising as legal (previously existing) norms of procedure addressed at an

2 R. Mastalski, Źródła prawa podatkowego w procesie jego stosowania, in: R. Mastalski and E. FojcikMastalska (eds.), Prawo Finansowe, Warszawa 2013, p. 178.

3 L. Morawski, Wstęp do prawoznawstwa, Toruń 2008, p. 91.

4 J. Kuciński, Tworzenie prawa podatkowego, źródła prawa, in: J. Kuciński (ed.), Zarys prawa, Warszawa 2010, p. 31.

5 W. Góralczyk, Podstawy prawa, Warszawa 2004, p. 61.

6 S. Wronkowska, Podstawowe pojęcia prawa i prawoznawstwa, Poznań 2003, p. 21. 
abstractly defined addressee and assuming repeatability of behaviours of the norm addressees. A substantive expression of the aforementioned decisions comprises normative acts deemed to be the sources of law. Moreover, all sources of law in a given state constitute a system of law sources understood as a structural entirety of relations, illustrating both, what is common for the law and what differentiates it. ${ }^{7}$ The position of particular types of law sources in the system depends on the three types of factors. The first and basic one, which indicates the place of a given source of law in the system of law sources, is the position held by the authority from which this source comes. This place is considered in the context of the entire system of public authorities. The higher situated in the hierarchy of bodies, the higher the position of a given source of law in the system of law sources. Other factors influencing the place of a given source of law to a much lesser extent are the following: the contents of a given source of law and the mode in which a given source of law is made. ${ }^{8}$ It should also be remembered that sources of law establish a hierarchically constructed system in which each source has its own place. It has specific consequences. The sources of law of lower level cannot, in fact, include provisions contrary to the provisions of acts of the highest level. ${ }^{9}$

\section{Sources of making tax law}

The law as a set of norms of proceeding may be a result of various legislative facts, such as: law-making, contracts, shaping the case law and legislative precedence. However, it should be remembered that despite the fact that the significance of particular facts that make the law in various law systems is different, the tax law is universally based on two categories of law sources, that is, normative acts and international agreements. Nevertheless, the fact that the acts of normative law constitute the core of tax law sources is obvious. They accommodate acts including norms of general and abstract nature alike. ${ }^{10}$

The system of sources of universally binding law is included in Chapter III of the Constitution of the Republic of Poland. ${ }^{11}$ It refers to the law as the legislative

\footnotetext{
7 A. Łopatka, Prawoznawstwo, Warszawa 2000, p. 175.

8 J. Kuciński, op. cit., pp. 32-33.

9 W. Siuda, Elementy prawa dla ekonomistów, Poznań 2000, p. 27.

10 M. Duda, Standardy polskiego prawa podatkowego, in: P. Smoleń et al. (eds.), Prawo podatkowe, Warszawa 2014, p. 30.

11 Constitution of the Republic of Poland of 2 April 1997, Dz.U. (Journal of Laws) of 1997, No. 78, item 483 , as amended.
} 
form of activity of state bodies by introducing a system of law sources closed in objective and subjective terms, including: constitution, acts, ratified international agreements and regulations. Furthermore, in the areas of activity of the bodies which established thereof, the sources of universally binding law of the Republic of Poland also include local legal acts. It should also be noticed that Chapter III of the Constitution of the Republic of Poland introduces not only a closed catalogue of sources of universally binding law, but also an exemplary depiction of sources of domestic law. Therefore, the principle of a closed catalogue pursuant to Article 87 must be supplemented by taking into account other sources of law included in the Constitution, e.g. legislative decrees, parliamentary rules and regulations, collective labour agreements and contracts or universally binding judgments of the Constitutional Tribunal. The aforementioned principle may also be extended with sources admitted under the Constitution to be binding such as legislation of the European Union and international organisations. It is worth underlining that this principle requires confrontation with legislative practice phenomena with are not directly contradictory, e.g. judicial decisions or a custom as the source of law diversified within particular branches of law. ${ }^{12}$

Constitutional assumptions are reflected in the contents of the Tax Ordinance $\mathrm{Act}^{13}$, which introduces the legal definition of tax law provisions. In compliance with Article 3(2) TO, provisions of tax law mean the provisions of tax acts, provisions of double taxation agreements ratified by the Republic of Poland and other tax-related international treaties ratified by the Republic of Poland, as well as provisions of implementing regulations issued on the basis of the tax act. It is worth emphasizing that by using the concept of tax law provisions in the Tax Ordinance Act, the legislator indicates institutions that are regulated incompletely in the act analysed. The contents of the Tax Ordinance Act imply, in fact, that not all international agreements should be considered to be tax law provisions. It is underlined that a given international agreement must be ratified in order to be included in the tax law. It is especially important due to the fact that has already been mentioned, that is, pursuant to Article 87(1) of the Constitution of the Republic of Poland, sources of universally binding law of the Republic of Poland include, apart from the Constitution and acts, ratified international agreements and regulations. While

12 A. Bałaban, Konstytucyjny system źródeł prawa po 15 latach obowiazywania (tezy), in: A. Bałaban et al. (eds.), Źródła prawa w Rzeczypospolitej Polskiej. W 15 lat po wejściu w życie Konstytucji z 2 kwietnia 1997 roku, Szczecin 2013, p. 10.

13 Act of 29 August 1997 - the Tax Ordinance Act, Dz.U. (Journal of Laws) of 2020, item 1325, hereinafter: TO. 
analysing the said provision of the Tax Ordinance Act, it is worth noticing the other group of provisions comprising implementing acts issued on the grounds of tax acts. It leads to the conclusion that this concept will not cover implementing acts, if they are not issued on the grounds of an act, i.e. they do not fulfil the conditions specified in the definition of the tax act. It should be underlined that the legislator includes regulations and local law acts, such as resolutions of municipal councils on tax rates or exemptions as tax law provisions. ${ }^{14}$

In the context discussed, judicial decisions underline that provisions of the Act of 27 August 2004 on healthcare benefits financed with public funds ${ }^{15}$ are not tax law provisions under the Tax Ordinance Act. This view was shared by the Supreme Administrative Court in its judgment of 15 May 2015. ${ }^{16}$ Moreover, pursuant to the Tax Ordinance Act, tax provisions of other countries are not tax law provisions either. Therefore, it was stated that "the Danish civil and tax law is a foreign law with regard to the Polish law and thus it cannot be the subject of interpretation of the Minister of Finance, since pursuant to Article $14 \mathrm{~b}(1)$ in conjunction with Article 3(2) of the TO, he only interprets the Polish law and international agreements related to tax issues to which Poland is a Party". ${ }^{17}$ However, legal scholars and commentators believe that the obligation of the body issuing an interpretation is to apply both a correct and complete interpretation of domestic law. However, if the case requires the use of an interpretation of a foreign law, it should also be applied. ${ }^{18}$ Therefore, the fact that the aim of the definition of tax law provisions quoted included in the Tax Ordinance Act is not to define legislative competences of public authorities, but to technically determine the indicated concept for the purposes of the Tax Ordinance Act itself, should be underlined. ${ }^{19}$ It leads to the conclusion that while analysing the sources of tax law both, the local and European Union law should be taken into consideration.

14 M. Popławski, Komentarz do art. 3 Ordynacji podatkowej, in: L. Etel (ed.), Ordynacja podatkowa. Komentarz, Warszawa 2017, p. 60.

15 Act of 27 August 2004 on healthcare benefits financed from public funds, Dz.U. (Journal of Laws) of 2020 , item 1398.

16 Judgement of the Supreme Administrative Court of 15 May 2015, II FSK 977/13, LEX No. 1774678.

17 Judgement of the Voivodeship Administrative Court in Warszawa of 8 January 2014, III SA/Wa 1982/13, LEX No. 1545012.

18 K. Lasiński-Sulecki, Glosa do wyroku NSA $z 11$ marca 2010 r., I FSK 61/09, OSP 2011, No. 5, item 54 .

19 Judgement of the Constitutional Tribunal of 9 November 1999, K 28/98, OTK 1999, No. 7 , item 156. 
To conclude, tax law provisions can be found not only in legal acts which in their titles have been defined as tax law acts, i.e. in the Tax Ordinance Act or the Regulation of the Minister of Finance of 24 December 2002 on tax information ${ }^{20}$, but also in legal acts regulating some tax-related issues. Those include, among others: the act of 29 August 1997 on NBP ${ }^{21}$ regulating the principles of the central bank's functioning i.e. exempting NBP from taxes and stamp duty, as well as the act of 27 July 2005 - Law on Higher Education ${ }^{22}$, indicating the subject of activity of universities exempt from some taxes. ${ }^{23}$

\section{Sources of tax law in the Constitution of the Republic of Poland}

The Constitution of the Republic of Poland constitutes a foundation on which the edifice is built with other sources of law, which combined constitute the legal system that is formally related and harmonised in terms of content. ${ }^{24}$ The Constitution of the Republic of Poland, being the source of tax law, shapes basic principles regarding creation, application and interpretation of the tax law and sets a framework in which entities formulating the construction of taxes and practical use thereof should operate. It may be stated that the Constitution of the Republic of Poland is a type of a guarantee of tax bearer's rights demonstrated in the principle of the democratic rule of law. In fact, provisions of the highest legal act directly refer to the tax issues, among others, in Articles 84 and 217. Pursuant to Article 84 of the Constitution of the Republic of Poland, everyone is obliged to fulfil tax obligations and public dues, including taxes, specified in the act. Therefore, the aforementioned provision introduces the principle of universality of taxation. It should be underlined that the discussed Article was included in the part of the Constitution of the Republic of Poland devoted to the obligations of persons and citizens and the principle of fiscal sovereignty resulting therefrom indicates that the state has the

20 Regulation of the Minister of Finance of 24 December 2002 on tax information, Dz.U. (Journal of Laws) of 2017, item 68.

21 Act of 29 August 1997 on Narodowy Bank Polski, Dz.U. (Journal of Laws) of 2020, item 2027.

22 Act of 27 July 2005 - Law on Higher Education, Dz.U. (Journal of Laws) of 2017, item 2138 - this act is no longer binding, since it has been replaced with the Act of 20 July 2018 - Law on Higher Education and Science, Dz.U. (Journal of Laws) of 2020, item 85.

23 Z. Ofiarski, Rozporządzenie jako źródło prawa podatkowego, in: A. Bałaban et al. (eds.), Źródła prawa w Rzeczypospolitej Polskiej. W 15 lat po wejściu w życie Konstytucji z 2 kwietnia 1997 roku, Szczecin 2013, p. 79.

24 E. Smoktunowicz, J. Mieszkowski, Źródła i wykładnia prawa podatkowego, Białystok 1998, p. 13. 
right to burden entities under its control in order to finance its tasks. ${ }^{25}$ From the formal-legal point of view, Article 84 of the Constitution of the Republic of Poland guarantees the statutory form of tax regulation and in this context Article 217 of the Constitution constitutes its extension. In compliance with the contents thereof that impose taxes and other public levies, determining subjects and objects of taxation, as well as tax rates, and the principles of granting reliefs and redemptions, as well as categories of entities exempt from taxes is done by means of an act. This provision is an illustration of the principle of a statutory form of taxation, since it grants the act the exclusivity to introduce basic elements of tax construction. ${ }^{26}$ It should be noticed that Article 217 of the Constitution was accommodated in the chapter concerning public finances that is in the chapter that includes norms primarily addressed to state bodies. Nevertheless, content thereof directly refers to the civic duty to maintain the state. ${ }^{27}$ Furthermore, it is worth remembering that apart from the provisions directly addressing tax issues, general principles of law that also apply to the tax law are also defined in the Constitution of the Republic of Poland. They include, among others: the principle of equality of all citizens before the law included in Article 32 of the Constitution, or the principle of the democratic rule of law and social justice referred to in Article 2 of the legal act discussed. At this point, it should also be emphasised again that the Constitution differentiates universally binding legal provisions and acts of domestic law. The tax bearer's legal situation can be, in fact, regulated only by stipulating the universally binding law. Thus, it may be concluded that acts of domestic tax law, i.e. resolutions of the Council of Ministers, orders of the Prime Minister or orders of ministers, as devoid of the universally binding law nature, cannot constitute the basis for obligatory activities outside the sphere of their domestic legal force, since crossing the sphere of these relations would constitute application of a domestic law provision in a manner that influences the tax bearer's legal situation. Moreover, domestic tax law provisions cannot replace universally binding acts of tax law, change or modify them.

To sum up, constitutional solutions concerning the sources of making tax law consequently translate into constitutional principles of tax law application. Therefrom, three universal principles can be derived. The first one indicates that an interpretation of tax provisions that would infringe constitutionally guaranteed rights and freedoms of an individual and economic rights or that would be

25 Judgement of the Constitutional Tribunal of 20 June 2002, K 41/02, OTK 2002, No. 6, item 83.

26 R. Wolański, System podatkowy w Polsce, Warszawa 2016, p. 62.

27 M. Duda-Hyz, Źródła i zasady tworzenia prawa podatkowego, in: P. Smoleń et al. (eds.), Prawo podatkowe, Warszawa 2017, p. 33. 
contradictory thereto, is inadmissible. The next one underlines that an interpretation of tax provision that infringes or is contradictory to the ratified international agreements on taxation is inadmissible. The last one underlines that in the case of significant and basic doubts that cannot be levelled and which are related to tax law provisions, an interpretation that corresponds to the principles included in the Constitution of the Republic of Poland to the largest extent should be applied. ${ }^{28}$

\section{Acts as sources of tax law}

Acts constitute a basic source of tax law. Prevalence of this type of a legal act in the structure of sources of law results directly from Article 217 of the Constitution of the Republic of Poland. In the law science an act is defined as a normative act adopted by the parliament in a special procedure specified in the Constitution, with an unlimited material scope of regulation and the with highest legal force next to the Constitution. ${ }^{29}$ It is worth emphasising in compliance with the position of the Constitutional Tribunal ${ }^{30}$ that all acts have the same legal rank in the Polish system of law sources and thus, there are no grounds for assigning any act with a special position. However, it does not mean that all acts have the same significance from the point of view of a state organism. Nowadays, public finances are one of the most important aspects of the state's functioning. This sphere covers both, the numerous tax acts and the budget act. Nonetheless, one should take into account the fact that, despite far-reaching functional relations with public levies, legal-tax contents cannot be included in the budget act. ${ }^{31}$

Interestingly, the Constitution of the Republic of Poland does not define the concept of a tax act. Moreover, the Constitutional Tribunal is of the opinion that "a tax act" and "a levy act" (included in Article 217 of the Constitution of the Republic of Poland), are not synonymous concepts. The act on the grounds of which a tax or other public levy is imposed has, in fact, a broader scope of meaning. It is specifically confirmed in practice, since taxes constitute one of the types of public levies and not the other way round.

28 A. Gomułowicz, D. Mączyński, Podatki i prawo podatkowe, Warszawa 2016, p. 187.

29 E. Gdulewicz, Konstytucyjny system źródeł prawa, in: W. Skrzydło (ed.), Polskie prawo konstytucyjne, Lublin 2000, p. 190.

30 Judgment of the Constitutional Tribunal of 12 January 1995, K 12/94, OTK 1995, No. 1, item 2.

31 A. Krzywoń, Podatki i inne daniny publiczne w Konstytucji Rzeczypospolitej Polskiej, Warszawa 2011, p. 233. 
However, the concept of a tax act was defined in another legislative act, i.e. in the Tax Ordinance Act. Pursuant to TO, a tax act means an act concerning taxes, fees and non-tax budgetary receivables, stipulating the subject and object of taxation, chargeable event, tax basis, tax rates and regulating the rights and obligations of tax authorities, tax bearers, taxpayers and collectors, as well as their legal successors and third parties. Therefore, it can be noticed that the content of the tax act differs from the levy act referred to in the Constitution of the Republic of Poland. The TO adopts, in fact, a much wider understanding of a tax act in comparison with the constitutional definition of a levy act. Nevertheless, the issue consists in the fact that pursuant to Article 3(1) TO, it is assumed that tax acts both regulate the construction of a given tax or other burden being a public levy and shape the rights and obligations of tax authorities and third parties. It leads to the conclusion that the tax act category can also include the act - Tax Ordinance Act, despite the fact that it does not benefit from the constitutional protection given to acts of a stricte tax nature in Article 217 of the Constitution of the Republic of Poland. ${ }^{32}$

In the Polish legal system a rule of regulating each tax with a separate act was adopted, which determines the position of a given act in the legal system and its possible relation to other acts. ${ }^{33}$ The only exceptions to this rule concern the act on local taxes and fees regulating both the property tax and the vehicle tax, as well as the act on gambling regulating the gambling tax.

While analysing the act as the source of tax law it should be underlined again that under a constitutional regulation, a principle of absolute exclusivity of the tax act in the strictly specified scope was introduced to the Polish tax system. The aforementioned principle has to be understood both, as an especially significant guarantee of the tax bearer's rights against public authorities and a guarantee of inviolability of Parliament's prerogatives. ${ }^{34}$ Furthermore, it is worth emphasising that Article 217 of the Constitution of the Republic of Poland leaves a small scope for implementing regulations and thus underlines that the universally binding tax law system cannot include a regulation that exceeds its statutory nature and enters into the subject matter reserved for the absolute exclusivity of the tax act. Consequently, a tax act cannot include an authorisation to stipulate the elements of a legal construction of a tax covered with the scope of absolute statutory exclusivity.

32 C. Kosikowski, Komentarz do art. 3 Ordynacji podatkowej, in: L. Etel (ed.), Ordynacja podatkowa. Komentarz, Warszawa 2013, p. 49.

33 S. Wronkowska, M. Zieliński, Komentarz do zasad techniki prawodawczej, Warszawa 2004, p. 57.

34 A. Gomułowicz, D. Mączyński, op. cit., pp. 187-188. 
Therefore, the authorisation defined in a tax act to issue implementing provisions has to be constitutional in itself.

\section{The international law and the European Union law as sources of tax law}

International law norms may be sources of tax law. Pursuant to Article 91 of the Constitution of the Republic of Poland, "after promulgation thereof in the Journal of Laws of the Republic of Poland (Dziennik Ustaw), a ratified international agreement shall constitute part of the domestic legal order and shall be applied directly." An exception thereto is a situation when application of such an agreement depends on the issuance of the act, whereas, the ratified international agreement, upon prior consent expressed in the act, can take precedence over an act where the act cannot be reconciled with the agreement. It is also worth noticing the nature of the act that gives this consent. It has a form of a peculiar formal act which is not aimed at transferring legal norms. Its task consists in giving the approved international agreement higher legal force than its own. ${ }^{35}$ In the Polish tax law, international law norms accommodated in the internal legal order include, among others, double taxation agreements and norms stipulated by international organisations. Apart from international agreements, the tax subject matter is also regulated by national norms referring to cross-border actual state of affairs. ${ }^{36}$ However, in the Polish tax law, double taxation agreements are of crucial importance. The basic aims of such agreements are presented in the provisions of the Organisation for Economic Cooperation and Development (OECD) Model Tax Convention. The basic function of double taxation agreements consists in striving to "make the situation of tax bearers of one state who conduct trade, industrial or financial activity in another state transparent, uniform and guaranteed by all states' applying shared solutions for identical cases in the scope of double taxation". ${ }^{37}$ Provisions of the above-mentioned convention prevent the most frequent issues in the scope of double taxation. ${ }^{38}$

The primary source of law binding in the territory of Poland, which is a member of the European Union, is the Treaty concerning the accession of the Republic of

35 A. Bałaban, Polskie problemy ustrojowe, Zakamycze 2003, p. 95.

36 P. Selera, Międzynarodowe a unijne prawo podatkowe $w$ kontekście opodatkowania zysków przedsiębiorstw, Warszawa 2010, p. 86.

37 D. Antonów, Źródła, wykładnia i stosowanie prawa podatkowego, in: P. Borszowski (ed.), Prawo podatkowe z kazusami i pytaniami, Warszawa 2018, p. 40.

38 R. Mastalski, Źródła, op. cit., p. 187. 
Poland to the European Union signed in Athens. ${ }^{39}$ It is governed by general principles of the Vienna Convention on the law of treaties of 23 May $1969^{40}$, to which Poland and other Member States are Parties. By joining the EU pursuant to the Accession Treaty, Poland transferred certain competences of public authorities outside the Constitutional state apparatus, including, to a certain extent, competences to making tax law. Such activity is compliant with the principles adopted in the Constitution of the Republic of Poland, since pursuant to Article 90(1), Poland may, by virtue of international agreements, delegate to an international organisation or international institution the competence of organs of State authority in relation to certain matters. It means that the European Union law (primary and secondary) has its place in the sources of law regulated in the Constitution of the Republic of Poland, but only with regard to the roots thereof. It is also worth emphasizing the primary sources of the European Union law, i.e. the Treaty on European Union ${ }^{41}$, the Treaty of Lisbon ${ }^{42}$, accession treaties and so-called general principles of law that are the sources of public international law. The European Union law stipulates, in fact, a legal order which is separate from the national and international public law. The indicated new order plays a significant role in the process of applying tax law functioning in the territory of Poland. ${ }^{43}$

However, provisions of the Union tax law can collide with provisions of the international tax law. In such a case it is necessary to stipulate mutual relations among these sources of law. In the situation when Poland concluded with a given state a double taxation agreement, first, it should be verified if this state is the EU Member State. This determines the field of interpretation of legal provisions necessary to settle collisions of international law and European Union law norms. ${ }^{44}$

39 Treaty concerning the accession of the Republic of Poland to the European Union of 16 April 2003, Dz.U. (Journal of Laws) of 2004 No. 90, item 865.

40 Vienna Convention on the law of treaties of 23 May 1969, United Nations, Treaty Series, vol. 1155, p. 331.

41 Treaty on European Union - consolidated version. OJ C 326, 26.10.2012, p. 13-390.

42 Treaty of Lisbon amending the Treaty on European Union and the Treaty establishing the European Community, signed at Lisbon, 13 December 2007, OJ C 306, 17.12.2007, p. 1-229.

43 R. Mastalski, Prawo podatkowe, Warszawa 2014, p. 89.

44 R. Mastalski, Źródła, op. cit., p. 191. 


\section{Regulations as sources of tax law}

A regulation is an act issued by the executive authorities deemed by the Constitution of the Republic of Poland as the source of universally binding law. It means that any implementing regulation addressed at entities not organisationally subject to the authority issuing a normative act has to take the form of a regulation. ${ }^{45}$ The normative act indicated is issued by the bodies identified in the Constitution of the Republic of Poland and more accurately, in Article 92, which strictly specifies the subject, time and situation in which a regulation can be issued. To be precise, it can be done by the Council of Ministers and particular ministers on the grounds of and within a detailed authorisation included in the act and for the purposes of implementation thereof. The authorisation should indicate a body relevant for issuing a regulation and a scope of matters submitted for regulation, as well as guidelines regarding the content of the act. However, the guidelines do not have to be put in the provision including a statutory authorisation. They can also be included in other provisions of the act, if it is possible to reconstruct contents thereof. ${ }^{46}$ Nevertheless, there is a dispute among legal scholars regarding this issue. It is, in fact, considered by some that putting guidelines outside the authorising provision is not a good legislative procedure, since it prevents the reconstruction of guidelines, especially from provisions of acts other than the authorising act. ${ }^{47}$ In the case of the tax law, implementing acts are primarily the Minister of Finance's regulations. It is worth emphasising that with regard to tax regulations, the following phrases are included in acts: "the Minister of Finance shall specify" and "the Minister of Finance may specify". The first one means an obligatory obligation of the Minister of Finance and the second, optional. ${ }^{48}$ What is important, the body authorised to issue a regulation does not have the right to transfer its competences to another body. Such a principle resulted in the ban on creating so-called cascade authorisations. It happens because the authorisation to impose a given obligation on a specific entity governed by the law must result from the act or provision of the regulation which is issued only on the grounds and within a statutory, so-called, explicit authorisation. ${ }^{49}$ Moreover,

45 Judgement of the Constitutional Tribunal of 9 November 1999, K 28/98, OTK 1999, No. 7, item 156.

46 Judgement of the Supreme Administrative Court of 28 January 2009, I GSK 246/08, LEX No. 478247.

47 M. Duda-Hyz, op. cit., p. 41.

48 G. Szczodrowski, Polski system podatkowy, Warszawa 2007, p. 69.

49 Judgement of the Supreme Administrative Court of 10 September 2001, II SA 1973/00, LEX No. 54758. 
from the perspective of principles included in Article 217 of the Constitution of the Republic of Poland, it is not possible to introduce under a regulation a new public levy unknown to the act. It is of particular significance for tax law issues, since the scope of the subject matter possible to be regulated in the regulation is limited both by Article 92(1) and Article 217 of the Constitution. It leads to the conclusion that regulations to tax acts can include only provisions supplementary to the provisions intended for the statutory subject matter. Therefore, if the legislator resigns from too frequent interferences in the construction of taxes and from treating them as instruments of achieving short-term objectives, a positive impact of the presented principle on the tax law system can be stated. ${ }^{50}$

\section{Local law acts}

Local law acts constitute a source of law in the operating area of bodies which issued them. Therefore, these provisions apply to voivodeships, poviats and communes alike, while bodies competent to adopt them include voivodeship authorities (sejmik), poviat council and commune council, respectively. The Constitution of the Republic of Poland provides local government units (hereinafter: LGUs) with a share in public income in accordance with tasks vested in them. A part of fiscal sovereignty is transferred to LGUs on the grounds of Article 168 of the Constitution of the Republic of Poland, which stipulates that "to the extent established by statute, units of local government shall have the right to set the level of local taxes and charges." It means that the local tax law is established on the grounds of statutes. However, it is worth noticing that the Constitution does not regulate which LGUs have the right to set the level of local taxes and charges. However, legal scholars and commentators and the established line of judicial adopt a view that only a commune has its own income from taxes. Thus, local law acts are issued in the form of resolutions of commune councils. Nevertheless, it should be underlined that authorisations to establish tax rates granted to communes do not concern all taxes. In the Constitution of the Republic of Poland it is, in fact, expressly underlined that LGUs have competences to establish only the level of local taxes and charges, i.e. the property tax, the vehicle tax, the agricultural tax, the forestry tax and fees such as: local, trade, advertising or health resort fees. Furthermore, the legislator does not provide communes with unlimited freedom in regulating taxes. It only grants the rights to introduce additional tax exemptions and reliefs and the possibility to apply

50 Z. Ofiarski, Rozporządzenie..., op. cit., pp. 84-85. 
a lower tax rate with regard to their upper limit defined annually in the Minister of Finance's announcement. Therefore, it is worth underlining again that under the Constitution, local law acts cannot introduce tax burdens in a given territory. A tax obligation can only be imposed by an act. Interestingly, this principle is not violated by the institution of the so-called self-taxation of commune residents for public purposes, which can be introduced by way of a local referendum, since such a possibility is provided for in the act. ${ }^{51}$

\section{The subject matter of sources of law in selected judgments}

As has already been underlined, Article 84 of the Constitution introduces the principles of universality and equality of taxation. Therefore, as underlined by the Constitutional Tribunal, "while stipulating the normative contents of the tax obligation, the legislator should do so in compliance with constitutional principles of equality and fairness". ${ }^{52}$ Introduction of any exceptions in this scope should comply with the standards of the democratic rule of law and the principle of social justice more accurately expressed in Article 2 of the Constitution. However, it is worth emphasising that statutory discrepancies should have a strictly specific objective. In its judgment of 20 November 2002 the Constitutional Tribunal underlined that application of these exceptions should primarily benefit the implementation of the state economic policy aimed at stimulating economy, e.g. by investing in specific areas. ${ }^{53}$ Furthermore, in the judgment of 9 November $1999^{54}$, a still valid thesis that "no regulation exceeding the statutory level can be currently issued in the universally binding law system, which is not directly based on the act and which does not serve the implementation thereof pursuant to Article 92(1) of the Constitution" was emphasized. It leads to the conclusion that there are no such subject matters, which, without prior statutory regulation, could constitute regulations that exceed the statutory level. Thus, a statutory regulation is necessary within sources of the universally binding law. The aforementioned judgment explains one more important issue that is the specificity of the statutory regulation and the possibility of

51 M. Duda, op. cit., pp. 46-47.

52 Judgement of the Constitutional Tribunal of 22 October 2002, SK 39/01, OTK (A) 2002, No. 5, item 66.

53 Judgement of the Constitutional Tribunal of 20 November 2002, K 41/02, OTK (A) 2002, No. 6 , item 83.

54 Judgement of the Constitutional Tribunal of 9 November 1999, K 28/98, OTK 1999, No. 7 , item 156. 
introducing certain issues under a regulation. It seems obvious that it will depend on the area of the subject matter regulated. With regard to the criminal law the act has absolute exclusivity ${ }^{55}$, whereas there might be more room for implementing regulations in other legal fields. However, it should be underlined that the indicated space cannot lead "to vesting the authorised body with the possibility of regulating the whole subject matter, to which there are no direct references in the act, independently". ${ }^{56}$

These examples of judgments confirm the fact that the role of the Constitutional Tribunal in shaping actual boundaries of law sources is extremely important. They have, in fact, a significant impact both, on the process of law application and interpretation. ${ }^{57}$ Thus, the main aim of judgments issued by the Constitutional Tribunal consists in the elimination of possible interpretation that is non-compliant with the principles expressed in the Constitution. ${ }^{58}$

\section{Conclusion}

The Constitution of the Republic of Poland as a source of law of the highest level indicates hierarchical construction of the system of law sources recognising the Constitution of the Republic of Poland as the foundation on which the system of other law sources was established. The principle of exclusivity of an act specified in the Constitution with regard to essential construction elements of tax or other public levy contributed to the intensification of the process of ordering sources of tax law. It means that due to the constitutional standards regarding the tax act, implementing acts being the sources of tax law should supplement the regulation of the statutory subject matter within the content included by the tax act. Therefore, there are no doubts that in the light of constitutional standards, the role of implementing acts in the tax law should be marginal. ${ }^{59}$

While verifying the sources of tax law, it should be remembered that judicial decisions are not the sources of tax law. Legislative activity of respectively authorised bodies cannot be, in fact, identified with an individual settlement of specific cases by the courts. Judicial decisions constitute a process of applying tax law and

55 Judgement of the Constitutional Tribunal of 26 April 1995, K 11/94, OTK, part I, p. 137.

56 Judgement of the Constitutional Tribunal of 24 March 1998, K 40/97, OTK, No. 2, p. 72.

57 R. Mastalski, Wplyw orzecznictwa na stosowanie prawa podatkowego, "Ruch Prawniczy, Ekonomiczny i Socjologiczny" 2011, No. 2, p. 119.

58 Judgement of the Constitutional Tribunal of 11 December 2001, SK 1600, OTK ZU, No. 8, item 257.

59 Z. Ofiarski, Rozporzadzenie..., op. cit., pp. 88-89. 
not making it. Courts are not entitled to make the law and consequently, their judgments cannot be considered as the sources of tax law. Furthermore, interpretations of tax law done by tax authorities on the grounds of the Tax Ordinance Act's provisions are not sources of tax law, since these are provisions concerning a specific actual state of affairs with regard to a given entity and thus, do not show characteristics of a general and abstract norm. What is important, letters issued by the Minister of Finance including opinions of this institution's employees cannot be included in the sources of tax law either. These are, in fact, only a form of interpretation of tax law provisions. However, such opinions have often lead to interpretative disputes. In the current legal status, entire collections of this type of letters are issued, which often include contradictory explanations issued by the Ministry. ${ }^{60}$

\section{References}

Antonów D., Źródła, wykładnia i stosowanie prawa podatkowego, in: P. Borszowski (ed.), Prawo podatkowe z kazusami i pytaniami, Warszawa 2018.

Bałaban A., Konstytucyjny system źródeł prawa po 15 latach obowiazywania (tezy), in: A. Bałaban et al. (eds.), Źródła prawa w Rzeczypospolitej Polskiej. W 15 lat po wejściu w życie Konstytucji z 2 kwietnia 1997 roku, Szczecin 2013.

Bałaban A., Polskie problemy ustrojowe, Zakamycze 2003.

Duda M., Standardy polskiego prawa podatkowego, in: P. Smoleń et al. (eds.), Prawo podatkowe, Warszawa 2014.

Duda-Hyz M., Źródła i zasady tworzenia prawa podatkowego, in: P. Smoleń et al. (eds.), Prawo podatkowe, Warszawa 2017.

Etel L., Źródła prawa podatkowego, in: L. Etel (ed.), Prawo podatkowe. Zarys wykładu, Warszawa 2013.

Gdulewicz E., Konstytucyjny system źródeł prawa, in: W. Skrzydło (ed.), Polskie prawo konstytucyjne, Lublin 2000.

Gomułowicz A., Mączyński D., Podatki i prawo podatkowe, Warszawa 2016.

Góralczyk W., Podstawy prawa, Warszawa 2004.

Kosikowski C., Komentarz do art. 3 Ordynacji podatkowej, in: L. Etel (ed.), Ordynacja podatkowa. Komentarz, Warszawa 2013.

Krzywoń A., Podatki i inne daniny publiczne w Konstytucji Rzeczypospolitej Polskiej, Warszawa 2011.

Kuciński J., Tworzenie prawa podatkowego, źródła prawa, in: J. Kuciński (ed.), Zarys prawa, Warszawa 2010.

60 L. Etel, Źródła prawa podatkowego, in: L. Etel (ed.), Prawo podatkowe. Zarys wykładu, Warszawa 2013, pp. 49-50. 
Lasiński-Sulecki K., Glosa do wyroku NSA z 11 marca 2010 roku, I FSK 61/09, OSP 2011, No. 5, item 54.

Łopatka A., Prawoznawstwo, Warszawa 2000.

Mastalski R., Prawo podatkowe, Warszawa 2014.

Mastalski R., Źródła prawa podatkowego w procesie jego stosowania, in: R. Mastalski et al. (eds.), Prawo Finansowe, Warszawa 2013.

Morawski L., Wstęp do prawoznawstwa, Toruń 2008.

Ofiarski Z., Rozporządzenie jako źródło prawa podatkowego, in: A. Bałaban et al. (eds.), Źródła prawa w Rzeczypospolitej Polskiej. W 15 lat po wejściu w życie Konstytucji z 2 kwietnia 1997 roku, Szczecin 2013.

Popławski M., Komentarz do art. 3 Ordynacji podatkowej, in: L. Etel (ed.), Ordynacja podatkowa. Komentarz, Warszawa 2017.

Selera P., Międzynarodowe a unijne prawo podatkowe w kontekście opodatkowania zysków przedsiębiorstw, Warszawa 2010.

Siuda W., Elementy prawa dla ekonomistów, Poznań 2000.

Smoktunowicz E., Mieszkowski J., Źródła i wykładnia prawa podatkowego, Białystok 1998.

Szczodrowski G., Polski system podatkowy, Warszawa 2007.

Wolański R., System podatkowy w Polsce, Warszawa 2016.

Wronkowska S., Podstawowe pojęcia prawa i prawoznawstwa, Poznań 2003.

Wronkowska S., Zieliński M., Komentarz do zasad techniki prawodawczej, Warszawa 2004.

\section{CITATION}

Bajerska A., Sources of tax law in the Polish legal system, "Acta Iuris Stetinensis" 2021, No. 1 (Vol. 33), 9-25, 10.18276/ais.2021.33-01. 